\title{
From the editor
}

\author{
Harvey S. James Jr.
}

Published online: 17 June 2011

(C) Springer Science+Business Media B.V. 2011

A front page article in a May 2011 issue of the Wall Street Journal reported that an effort by Nasdaq, a small but important US electronic stock exchange, to merge with the New York Stock Exchange was denied by the U.S. Department of Justice. The reason given for the denial was that the merger "would destroy the intense competition that has lowered trading costs and given US companies a choice about where to list their shares" (Lucchetti and Catan, 2011, p. A1). Of course, the Nasdaq was disappointed with the decision. Its argument for the merger was that efficiencies resulting from an increase in size would allow it to compete with global exchanges and that it wanted "to avoid being left behind other exchanges that are joining forces" (p. A1).

As I read the article I thought, "It's about time the Department of Justice didn't buy the 'bigger will make us better' argument."

I was actually surprised at having this thought. As an economist, I should welcome efforts to promote efficiency, if "better" means "more efficient," since efficiency is one of the foundational concepts of economic theory. (Indeed, economists distinguish among many types of efficiency, such as Pareto, Kaldor-Hicks, X, allocative, productive, dynamic.)

Because the Department of Justice, along with the Federal Trade Commission, is responsible for enforcing US antitrust laws, the Department must approve mergers of US companies in order to ensure that market competition is not adversely affected. However, efficiency due to "economies

H. S. James Jr. $(\bowtie)$

Department of Agricultural and Applied Economics, University of Missouri, 146 Mumford Hall, Columbia, MO 65211, USA

e-mail: hjames@missouri.edu of scale or other 'synergies'” (Andrade et al. 2011, p. 103) is one of the most common reasons given by firms seeking to increase their size through merger or acquisition, and federal merger guidelines explicitly allow "mergers expected to increase market power if the merger would increase economic efficiency" (Murphy, 2007, p. 5). The result is that mergers expected to improve economic efficiency are approved even though market competition is reduced, if the economic benefits can (at least in theory) be passed on to consumers so that there is no net anticompetitive effect. The relevant concept here is "cognizable efficiencies," which means that expected efficiencies must be specifically attributable to the merger itself and be verifiable "by reasonable means". Quoting from the Horizontal Merger Guidelines of the US Department of Justice and Federal Trade Commission (1997, p. 32):

The greater the potential adverse competitive effect of a merger ... the greater must be cognizable efficiencies in order for the Agency to conclude that the merger will not have an anticompetitive effect in the relevant market. When the potential adverse competitive effect of a merger is likely to be particularly large, extraordinarily great cognizable efficiencies would be necessary to prevent the merger from being anticompetitive.

This is an interesting argument-that it is acceptable to reduce competition in an industry if doing so improves economic efficiency. It is interesting for two reasons. The first is because it suggests that there is a trade-off between competition and efficiency. The second is because economic theory states that competition is desirable because it promotes efficiency. Are these reasons compatible? In other words, if we want efficiency, do we have to give up competition, or do we promote it? 
I raise this issue because one of the most pressing concerns in agrifood studies involves consolidation, concentration and globalization of agrifood industries. Seed companies, meat packers, food processors, and grocery retailers are increasing market share, with fewer companies controlling larger shares of the market. For example, the most available evidence indicates that the top four firms control $84 \%$ of beef packers, $66 \%$ of pork packers, and $80 \%$ of soybean crushing, while the top three firms control $55 \%$ of flour milling (Hendrickson and Heffernan 2007).

There are a number of implications that arise from industry concentration, particularly in the agrifood sector. On the positive side, as suggested above, the merging and consolidation of firms and farms could capture economies of scale, resulting in increasing productivity and lower costs to downstream firms and consumers at the retail end (Paul et al. 2004; Nguyen and Ollinger 2006). On the negative side, industrial concentration could shift the balance of economic power away from farmers towards agrifood firms (Hendrickson et al. 2001) and result in a reduction in innovation and R\&D activity (Schimmelpfennig et al. 2004).

Initiating a series of cross-country workshops in 2010 on competition in the agrifood sector, US Attorney General Eric Holder said, "Is today's agriculture industry suffering from a lack of free and fair competition in the marketplace? That's the central question." Importantly, there is very little scholarship on this important issue.

I admit to having two minds on this issue (a typical failing of economists, in fact). On the one hand, I am partial to the efficiency argument. Sometimes bigger really is better. To drive this point, I admit that there is much I like about Wal-Mart (gasp, I know). Its size generates efficiencies, and the company uses those efficiencies to lower prices of the products sells, at least relative to many of its competitors. As a consumer, I like saving money, or, perhaps more accurately, I don't like finding out that I spent more on something than I could have. On the other hand, I am concerned that there are very real problems with the state of competition in the agrifood industry, and I worry about what the longterm implications of declining competition will mean for me personally and society in general. When there is competition, there is choice. For me, the ability to choose is just as important, if not more so, than the improvement of economic efficiency. I don't think I am ready to give up choice for greater efficiency.

But the problem here is more fundamental. Efficiency is a relative concept. Its assessment is made relative to something else. To say that $\mathrm{A}$ is efficient implies that there is a possibility of inefficiency, and that requires the existence of a reasonable alternative to $\mathrm{A}$, which in turn requires there to be a choice. When there is no choice, or when there are no options or alternatives, then how can we recognize efficiency? Ultimately, choice, and hence competition, must be preserved.

Readers of this journal will be pleased to know this journal remains a competitive leader in its field and is thus an excellent choice for discriminating scholars (I enjoy reminding my colleagues that the 2009 Impact Factor for Agriculture and Human Values is higher than that of the leading agricultural economics journals.). Therefore, in an effort to advance scholarship on agricultural issues and human values, this issue contains two research articles, one in-the-field report and a special symposium on private agrifood governance. The issue begins with an article by Welsh and Rivers, whose study of a sample of New York farmers reveals two distinct environmental management strategies. Johnston and Szabo's article is an investigation of the meaning and role of reflexivity in the shopping experiences of customers of Whole Foods Market. Hart's in-the-field report critically compares the efficacy of agricultural extension services with local knowledge in the production of South African household vegetable gardens, noting deficiencies and biases in some extension programs. The symposium on private agrifood governance is guest edited by Doris Fuchs, Agni Kalfagianni, Jennifer Clapp, and Lawrence Busch. In addition to their introduction, the symposium contains seven research papers and a final discussion piece by Spencer Henson. I commend the guest editors for an outstanding contribution to the literature on global food governance.

\section{References}

Andrade, G., M. Mitchell, and E. Stafford. 2011. New evidence and perspectives on mergers. Journal of Economic Perspective 15(2): 103-120.

Hendrickson, M., and W. Heffernan. 2007. Concentration of agricultural markets. Columbia, MO: Department of Rural Sociology, University of Missouri. http://www.foodcircles.missouri.edu/ 07contable.pdf. Accessed 17 Nov 2010.

Hendrickson, M., W. Heffernan, P.H. Howard, and J. Heffernan. 2001. Consolidation in food retailing and dairy. British Food Journal 103(10): 715-728.

Lucchetti, A., and T. Catan. 2011. Feds sink Nasdaq's bid to buy big board. Wall Street Journal 17: A1-A2.

Murphy, E.V. 2007. Mergers and acquisitions: Primer on economic considerations in the FTC and DOJ horizontal merger approval process. Washington, DC: Library of Congress, Congressional Research Service. http://www.policyarchive.org/handle/10207/ bitstreams/4451.pdf. Accessed 18 May 2011.

Nguyen, S., and M. Ollinger. 2006. Mergers and acquisitions and productivity in the US meat products industries: Evidence from the micro data. American Journal of Agricultural Economics 88(3): 606-616.

Paul, C., R. Nehring, D. Banker, and A. Somwaru. 2004. Scale economies and efficiency in US agriculture: Are traditional farms history? Journal of Productivity Analysis 22(3): 185-205. 
Schimmelpfennig, D.E., C.E. Pray, and M.F. Brennan. 2004. The impact of seed industry concentration on innovation: a study of US biotech market leaders. Agricultural Economics 30: 157-167.
US Department of Justice and Federal Trade Commission. 1997. Horizontal Merger Guidelines. Washington, DC: US Department of Justice and Federal Trade Commission. http://www.justice.gov/ atr/public/guidelines/hmg.pdf. Accessed 18 May 2011. 